\title{
Comparison among Different Integrated Nutrition Management for Soil Micro and Macro Elements after Winter Wheat Harvesting and Yield
}

\author{
Aydin KHODAEI JOGHAN, Amir GHALAVAND, Majid AGHAALIKHANI, \\ Majid GHOLAMHOSEINI and Aria DOLATABADIAN \\ Tarbiat Modares University, Faculty of Agriculture, Agronomy Department, Tehran, Iran; Ghalavand_amir@yahoo.com, (correspondingautor)
}

\begin{abstract}
A comparative field experiment has been conducted in order to study the effect of chemical, organic and integrated nitrogen suppliment on micro and macro nutrient residue after wheat harvesting, at Faculty of Agriculture, Tarbiat Modares University, Tehran, Iran. The treatments consisted in three groups that are chemical, organically and integrated of them. Nitrogen was supplied in different proportion from chemical and organic sources. Also, zeolite was applied in two ways: mixed with soil and mixed with cattle manure during composting. Before sowing and after wheat harvesting, macro and micro nutrient availability in the soil were examined. The results showed that, among treatments supplying with 100\% nitrogen required from composted cattle manure amended with $10 \%$ (w/w) zeolite had the best effect on nutrition residue after wheat production because zeolite decreased nitrogen leaching during the manure composting. Crop yield was not statistically different between fertilizer treatments but the highest seed yield was achieved from supplying $50 \%$ nitrogen required from cattle manure compost and 50\% by urea amended with $10 \%(\mathrm{w} / \mathrm{w})$ zeolite. This study demonstrated that composted cattle manure amended with zeolite improves soil fertility after wheat production compared with chemical fertilization.
\end{abstract}

Keywords: cattle manure, compost, micro and macro nutrient, nitrogen, zeolite

\section{Introduction}

Low organic matter is one of the major constraints affecting the productivity of the soils. Organic matter is an important soil component in improving soil physical properties. This is essential to sustaining the productivity of soils particularly in semi- arid regions where there is a low input of organic matter. Organic matter affects crop growth and yield either directly by supplying nutrients or indirectly by modifying soil physical properties such as stability of aggregates and porosity that can improve the root environment and stimulate plant growth (Darwish et al., 1995). Manure and compost are organic sources of nutrients that also increase soil organic matter content and improve the soil quality (Wright et al., 1998). Application of manure or composted manure can result in increased soil concentrations of nutrients and organic matter (Eghball, 2002). The residual effects of increased nutrients and organic matter in soil following manure or compost application on crop yield and soil properties can last for several years (Mugwira, 1979). Organic fertilizers, such as cattle manure, have a long and sustained practical use since they are been known to improve physical, chemical and biological properties of the soils, particularly increasing the humus content and decreasing acidity (Ganzhara, 1998). In recent years, fertilizer cost and concern for sustainable soil productivity and ecological stability in relation to chemical fertilizer use have emerged as an important issues (Aulakh and Pasricha, 1997). Therefore, any integrated nutrient management practice that can improve organic matter status and nitrogen availability of soil is important to attain sustainable production. Soil amendments such as zeolites have important role in improving the soil fertility and in prevention of nutrition looses. Zeolites are a group of minerals, highly crystalline hydrated aluminosilicates that, when dehydrated, develop a porous structure with minimum pore diameters between 3 to $10 \AA$. The structural frame is made up of $\mathrm{Si}-\mathrm{O}\left(\mathrm{SiO}^{44-}\right)$ and $\mathrm{Al}-\mathrm{O}\left(\mathrm{AlO}^{45-}\right)$ tetrahedrons, which bond together sharing vertices and forming square and hexagonal structures. There are several zeolite types, one of them being clinoptilolite, a hydrated alumosilicate of alkali and alkaline earth metals $\left(\mathrm{Na}^{+}, \mathrm{K}^{+}\right.$, $\left.\mathrm{Ca}^{2+}, \mathrm{Mg}^{2+}, \mathrm{Ba}^{2+}\right)$ having an infinite three-dimensional crystal structure, a polyedric shape and a great open cavity (Daković et al., 2007). Zeolites can be successfully used in cultivating different crops such as cereals, forage crops, vegetables, vine and fruit crops due to their exceptionally high ion-exchange capacity (Butorac et al., 2002). Zeolites prevent unnecessary losses of nutrients, making them available exactly when needed (Podlešáková et al., 1967). Zeolites as carriers of $\mathrm{N}$ and $\mathrm{K}$ fertilizers, increase their efficacy by decreasing application rates, for equal yields to be achieved (Polat et al., 2004).

Recently, integrated nutrient management involving organic manure and chemical fertilizer has received considerable attention. Thus, an experiment was conducted to study the comparison among different integrated nutrition management solutions for wheat yield and note the 
108

changes of the chemical properties of the soil after wheat harvesting. Also, zeolite was applied as soil and manure amendments two way combinations with cattle manure, during composting and soil application.

\section{Materials and methods}

A field experiment was conducted in the research farm of Faculty of Agriculture, Tarbiat Modares University, Tehran, Iran $\left(35^{\circ} 41^{\prime} \mathrm{N}\right.$ latitude, $51^{\circ} 19^{\prime} \mathrm{E}$ longitude and $1215 \mathrm{~m}$ altitude) during the 2007 wheat growing seasons. The yearly average precipitation (30-years long term period) which is mostly occurred during the autumn and winter months was $298 \mathrm{~mm}$. The experimental filed was tilled with moldboard-plow and disk in autumn. The previous crop was sweet corn (Zea mays L.). The experimental plot's surface were $3.5 \times 2 \mathrm{~m}$, with ten sowing rows. Between all before composting. The results showed that, fresh cattle manure had $2.75 \%$ nitrogen. Other results are shown in Tab. 2 and Tab. 3, respectively.

In order to composting, two rows of weighted cattle manure were stored in heaps of $5 \mathrm{~m}$ long, $0.8 \mathrm{~m}$ wide and $0.7 \mathrm{~m}$ high and then zeolite was added into one of them in proportion of $10 \%(\mathrm{w} / \mathrm{w})$ of the complete weight of cattle manure. To prevent of direct sun light, the heaps were covered by straw and stubble. The temperature and moisture of heaps were monitored daily. Manure rows were aerobically composted for 85 days. At the end of the composting process one composite sample of each row was collected and analyzed. It was observed that 38\% nitrogen was lost in without zeolite row, while the nitrogen loss was $22 \%$ in zeolite applied row, during the composting process. Therefore, nitrogen percentage was $2.1 \%$ and $1.7 \%$ in rows containing zeolite and without zeolite, respectively. It is

Tab. 1. Physical and chemical soil properties

\begin{tabular}{|c|c|c|c|c|c|c|c|c|c|c|}
\hline \multirow[b]{2}{*}{ Physical } & Depth & Sand & Silt & Clay & Texture & F.C & C.E.W & A.W & $\mathrm{B}_{\mathrm{d}}$ & $\mathrm{pH}$ \\
\hline & $0-30 \mathrm{~cm}$ & $69 \%$ & $20 \%$ & $11 \%$ & $\begin{array}{l}\text { Sandy } \\
\text { loam }\end{array}$ & $21 \%$ & $9 \%$ & $12 \%$ & $1.45 \mathrm{gr} \mathrm{cm}^{-2}$ & 7.7 \\
\hline \multirow{2}{*}{ Chemical } & \multirow{2}{*}{$0-30 \mathrm{~cm}$} & CEC & O.C & $\mathrm{N}$ & $\mathrm{P}$ & $\mathrm{K}$ & $\mathrm{Fe}$ & $\mathrm{Cu}$ & $\mathrm{Zn}$ & $\mathrm{Mn}$ \\
\hline & & $4.6 \mathrm{meq} / 100 \mathrm{gr}$ & $1.06 \%$ & $0.07 \%$ & $>12 \mathrm{ppm}$ & $>350 \mathrm{ppm}$ & $7.6 \mathrm{mg} \cdot \mathrm{Kg}^{-1}$ & $0.7 \mathrm{mg} \cdot \mathrm{Kg}^{-1}$ & $1 \mathrm{mg} \cdot \mathrm{Kg}^{-1}$ & $15 \mathrm{mg} \cdot \mathrm{Kg}^{-1}$ \\
\hline
\end{tabular}

F.C: Field Capacity; C.E.W: Crop Extractable Water; A.W: Available Water; Bd : Bulk Density; CEC: Cation Exchange Capacity; O.M: Organic Matter; N: Total Nitrogen; P: Absorbable Phosphorous; K: Absorbable Potassium

plots, $1 \mathrm{~m}$ alley was kept to prevent all influence of lateral water movement. The experimental design was a randomized complete block with three replications. After seed bed preparation, a composite soil sample at depth of $30 \mathrm{~cm}$ was taken before treatments application from each plot. Soil samples were air-dried, ground to pass a $1-\mathrm{mm}$ sieve, and analyzed for NPK, micronutrient $(\mathrm{Cu}, \mathrm{Zn}, \mathrm{Fe}, \mathrm{Mn})$ and organic carbon statues. Physical and chemical properties of the soil are shown in Tab. 1.

Three month before filed preparation, cattle manure and zeolite were transported to the study site. The chemical characteristic of cattle manure and zeolite were analyzed

Tab. 2. Fresh cattle manure properties

\begin{tabular}{ccccccc}
\hline E.C & $\mathrm{N}$ & $\mathrm{P}$ & $\mathrm{K}$ & $\mathrm{Na}$ & $\mathrm{O} . \mathrm{C}$ & $\mathrm{O} . \mathrm{M}$ \\
\hline $21.2 \mathrm{dS} \mathrm{m}^{-1}$ & $2.75 \%$ & $0.56 \%$ & $2.55 \%$ & $1.22 \%$ & $28.85 \%$ & $49.91 \%$ \\
\hline S.C & ${\mathrm{C} . \mathrm{N}^{-1}}^{2}$ & $\mathrm{pH}$ & $\mathrm{Fe}$ & $\mathrm{Cu}$ & $\mathrm{Zn}$ & $\mathrm{Mn}$ \\
\hline $240 \%$ & 23 & 9 & $\begin{array}{c}7435 \\
\mathrm{mg} . \mathrm{Kg}^{-1}\end{array}$ & $\begin{array}{c}25.5 \\
\mathrm{mg} \cdot \mathrm{Kg}^{-1}\end{array}$ & $\begin{array}{c}109.3 \\
\mathrm{mg} . \mathrm{Kg}^{-1}\end{array}$ & $\begin{array}{c}267.6 \\
\mathrm{mg} . \mathrm{Kg}^{-1}\end{array}$ \\
\hline
\end{tabular}

E.C: Electrical conductivity; O.C: Organic Carbon; O.M: Organic Matter; S.C: Saturated Capacity

Tab. 3. Percentage of chemical compounds in applied zeolite

\begin{tabular}{cccccc}
\hline $\mathrm{SiO}_{2}$ & $\mathrm{AL}_{2} \mathrm{O}_{3}$ & $\mathrm{~K}_{2} \mathrm{O}$ & $\mathrm{Na}_{2} \mathrm{O}$ & $\mathrm{Mg} \mathrm{O}$ & $\mathrm{CaO}$ \\
\hline 65 & 12.02 & 3 & 1.08 & 0.1 & 2.3 \\
\hline $\mathrm{Fe}_{2} \mathrm{O}_{3}$ & $\mathrm{MnO}$ & $\mathrm{TiO}_{2}$ & $\mathrm{P}_{2} \mathrm{O}_{5}$ & $\mathrm{CEC}$ & $\mathrm{SO}_{3}$ \\
\hline 1.5 & 0.04 & 0.03 & 0.01 & $200 \mathrm{meq} / 100 \mathrm{gr}$ & - \\
\hline
\end{tabular}

reported that, $35 \%$ of the nitrogen is available during the first year (Eghball and Power, 1999) thus $0.7 \%$ and $0.6 \%$ nitrogen was available in with and without zeolite rows, respectively. In addition, chemical analysis of the composts showed that one $\mathrm{kg}$ compost of each row has 7.5 (with zeolite) and $6 \mathrm{~g}$ (without zeolite) nitrogen. According to wheat nitrogen requirement and soil nitrogen content it was calculated that $120 \mathrm{Kg} \cdot \mathrm{ha}^{-1}$ nitrogen was needed for wheat production. Nitrogen was supplied through urea, two type of composted cattle manure (with and without zeolite) and integrated of them in different proportions. Thus, $11.2 \mathrm{~kg}$ and $14 \mathrm{~kg}$ of each type of compost (with and without zeolite, respectively) should be used in $7 \mathrm{~m}^{2}$ plots to complete supply of wheat requirement (16 and 20 $\mathrm{t} / \mathrm{ha}^{-1}$, respectively). Based on this, other proportions are calculable.

At sowing time, 15 different treatments were randomized on each plot for each replication. There are five treatments included 9 ton.ha ${ }^{-1}$ zeolite which are introduced by $\mathrm{T}_{2}, \mathrm{~T}_{7}, \mathrm{~T}_{8}, \mathrm{~T}_{11}$ and $\mathrm{T}_{14}$. In these treatments prior to seed sowing 9 ton.ha ${ }^{-1}$ zeolite was broadcasted and mixed into the soil and then composted cattle manure, urea or integrated of them were applied. Note that, in treatments included the urea half of urea was used at sowing time and the rest was applied at jointing stage. According to results of the soil analysis, to $\mathrm{P}$ or $\mathrm{K}$ application was not needed.

Wheat seeds (Triticum aestivum L. c.v 'Pishtaz') were sowed in middle of November. A seed rate of $150 \mathrm{~kg} \mathrm{ha}^{-1}$ was used to maintain a plant population of 4 million 
plants.ha- ${ }^{-1}$. Irrigation was applied as required during the crop growing season.

The wheat was harvested in Jun 2008, and a final grain yield was recorded. After harvesting the composite soil samples at depth of $30 \mathrm{~cm}$ were taken from each plot again. Soil samples were air-dried, ground to pass a $1-\mathrm{mm}$ sieve, and analyzed for NPK, micronutrient $(\mathrm{Cu}, \mathrm{Zn}, \mathrm{Fe}$, $\mathrm{Mn})$ and organic carbon statues.

In two stages of soil analysing, total N, P and K were determined through titration method by Kjeltec Auto 1030 Analyzer, Tecator, calorimetric method by Spectrophotometer, 6505 JenWay and flame photometry by flame-photometer JenWay PFP7, respectively. Also, Cu, $\mathrm{Zn}, \mathrm{Fe}$ and $\mathrm{Mn}$ percentage were determined by atomic absorption method.

All data were analyzed using the analysis of variance (ANOVA) and GLM procedure in SAS. Duncan's multiple range tests was used to measure statistical differences between treatment methods and controls.

\section{Results and discussion}

The analysis of variance demonstrated that, soil micro and macro elements, organic carbon and wheat yield were significantly influenced by different nutrition management (Tab. 4).

Significant increases in Kjeldahl nitrogen content was observed in the full organically plots amended with zeolite. However, zeolite application as mixed form with manure had a more positive effect on soil nitrogen content than direct consumption ( Tab. 5). For the $\mathrm{T}_{4}$ treatment, the average nitrogen percentage was $0.347^{4}$, while the $\mathrm{T}_{7}$ treatment had $0.196 \%$ (Tab. 5). Other researchers also found higher nitrogen content in soil amended with organic residues (Scheller and Raupp, 2005; Warman, 2005). Therefore, the higher nitrogen contents in organic plots could be due in part to the nutrient supply with the composts and especially by the decrease of nitrogen leaching by zeolite during composting and growth season. The lowest soil nitrogen content $(0.033 \%)$ was observed in control treatment i.e. with no treatment (Tab. 5). Also, in full chemical treatments $\left(T_{1}\right.$ and $\left.T_{2}\right)$ soil nitrogen percentage was at the lowest level after wheat harvesting (Tab. 5). Because urea was easily leached while in integrated plots accompany with zeolite, residual nitrogen was higher than for the chemical treatments (Tab. 5). A higher level of microbial activity in organic soil compared with mineral soils is one of the most important reasons to soil nitrogen conservation. Studies that compare organic and mineral fertilization in soils show higher soil organic matter and total nitrogen for organic-amended soils (Bulluck et al., 2002; Warman, 2005). According to these results, supplying $100 \%$ nitrogen required from composted cattle manure amended with $10 \%(\mathrm{w} / \mathrm{w})$ zeolite is the best treatment to nitrogen conservation.

Soil analysis after crop harvesting showed that, phosphorous availability in full organically fertilized plots amended with zeolite $\left(\mathrm{T}_{4}\right)$ was significantly higher compared with other organic, chemical or integrated ones (Tab. 5). Also, the addition of $10 \% \mathrm{w} / \mathrm{w}$ zeolite as mixed with cattle manure during composting process was better than direct application of zeolite into the soil. The lowest phosphorous content was observed in chemical $\left(\mathrm{T}_{1}\right.$ and $T_{2}$ ) plots and control treatment $\left(T_{15}\right)$ (Tab. 5). There are two mechanisms to explain the increase of phosphorous availability in our experiments: (i) the use of composted cattle manure with a higher phosphorous content compared with the chemical fertilization (Tab. 2), and (ii) the decomposition of cattle manure could have resulted in concentrations of organic acids that effectively reduced phosphorous sorption into the soil and increase phosphorous availability (Laboski and Lamb, 2003). Ruiz (2002) reported that, the organic matter added can increase the availability of phosphorous in soil. In addition, microbial activity increases when organic matter is added to the soil, increasing $\mathrm{CO}_{2}$ release, which forms $\mathrm{H}_{2} \mathrm{CO}_{3}$ in the soil solution, resulting in the dissolution of primary phosphorous containing minerals and therefore increasing available phosphorous content (Tisdale et al., 1985). There is considerable evidence in the literature to suggest that the application of organic material to soil may increase phosphorous solubility (Sanyal and De Datta, 1991). Zeolites, when saturated with mono-valent nutrient cations, such as $\mathrm{NH}_{4}^{+}$and $\mathrm{K}^{+}$, have been reported to increase the solubility of phosphates (Allen et al., 1993). When zeolite was added into the cattle manure soil phosphorous availability was incrusted after crop harv esting. This result confirms that of (Allen et al., 1993) that the $\mathrm{NH}_{4}^{+}$-zeolite increased the amount of phosphorous availability.

Similar results have been obtained about potassium content of the soil. The highest values of available potassium were observed in the organic plots when zeolite was added into the cattle manure during composting (Tab. 5). The available potassium in organic plots increased com-

Tab. 4. Analysis of variance on micro and macro elements, organic carbon and seed yield affected by different nutrition management (the values in the table are mean squares)

\begin{tabular}{ccccccccccc}
\hline Sources & d.f & $\mathrm{N}$ & $\mathrm{P}$ & $\mathrm{K}$ & $\mathrm{Fe}$ & $\mathrm{Cu}$ & $\mathrm{Mn}$ & $\mathrm{Zn}$ & $\mathrm{O} . \mathrm{C}$ & Yield \\
\hline Block & 2 & $0.00^{* *}$ & $9038.64^{* *}$ & $391996.74^{* *}$ & $82.73^{* *}$ & $1.65^{* *}$ & $394.11^{* *}$ & $11.14^{* *}$ & $6.27^{* *}$ & $7246.42^{*}$ \\
Treatment & 14 & $0.01^{* *}$ & $14050.81^{* *}$ & $16495.33^{* *}$ & $3.74^{* *}$ & $0.04^{* *}$ & $19.96^{* *}$ & $0.91^{* *}$ & $0.12^{* *}$ & $9785.42^{* *}$ \\
Error & 28 & 0.00 & 105.38 & 192.72 & 0.47 & 0.00 & 0.41 & 0.01 & 0.00 & 1730.75 \\
CV & & 3.67 & 6.27 & 1.71 & 8.00 & 2.79 & 3.14 & 3.99 & 3.84 & 16.06 \\
\hline
\end{tabular}

**** significant at the 0.05 and 0.01 probability levels, respectively and ns no significant. 
Tab. 5. Comparison of means on micro and macro elements, organic carbon and seed yield affected by different nutrition management

\begin{tabular}{|c|c|c|c|c|c|c|c|c|c|c|}
\hline \multicolumn{2}{|c|}{ Treatments } & $\mathrm{N}(\%)$ & $\begin{array}{c}\mathrm{P} \\
\left(\mathrm{mg} \cdot \mathrm{Kg}^{-1}\right)\end{array}$ & $\begin{array}{c}\mathrm{K} \\
\left(\mathrm{mg} \cdot \mathrm{Kg}^{-1}\right)\end{array}$ & $\begin{array}{c}\mathrm{Fe} \\
\left(\mathrm{mg} \cdot \mathrm{Kg}^{-1}\right)\end{array}$ & $\begin{array}{c}\mathrm{Cu} \\
\left(\mathrm{mg} \cdot \mathrm{Kg}^{-1}\right)\end{array}$ & $\begin{array}{c}\mathrm{Mn}(\mathrm{mg} . \\
\left.\mathrm{Kg}^{-1}\right)\end{array}$ & $\begin{array}{c}\mathrm{Zn}(\mathrm{mg} . \\
\left.\mathrm{Kg}^{-1}\right)\end{array}$ & $\begin{array}{l}\text { O.C } \\
(\%)\end{array}$ & $\begin{array}{c}\text { Yield } \\
\left(\mathrm{kg} \cdot \mathrm{ha}^{-1}\right)\end{array}$ \\
\hline \multirow{4}{*}{ Chemical } & $\mathrm{T}_{1}$ & $0.137^{\mathrm{j}}$ & $82.40^{\mathrm{f}}$ & $723.86^{\mathrm{c}}$ & $7.55^{\mathrm{c}}$ & $1.07^{\mathrm{d}}$ & $17.45^{\mathrm{dc}}$ & $2.98^{\mathrm{f}}$ & $1.63^{\mathrm{cf}}$ & $2566.7^{\text {bcdc }}$ \\
\hline & $\mathrm{T}_{2}$ & $0.141^{\mathrm{ij}}$ & $88.33^{\mathrm{f}}$ & $726.09^{c}$ & $7.76^{\mathrm{bc}}$ & $1.07^{\mathrm{d}}$ & $16.72^{\mathrm{c}}$ & $3.03^{\mathrm{cf}}$ & $1.65^{\mathrm{cf}}$ & $2659.0^{\mathrm{bcd}}$ \\
\hline & $\mathrm{T}_{3}$ & $0.182^{c}$ & $225.33^{b c}$ & $930.20^{a}$ & $10.35^{\mathrm{a}}$ & $1.27^{\mathrm{b}}$ & $23.02^{b}$ & $4.02^{\mathrm{b}}$ & $2.14^{a}$ & $2367.7^{\text {cde }}$ \\
\hline & $\mathrm{T}_{4}$ & $0.347^{\mathrm{a}}$ & $267.82^{\mathrm{a}}$ & $930.48^{\mathrm{a}}$ & $10.32^{\mathrm{a}}$ & $1.39^{\mathrm{a}}$ & $24.54^{\mathrm{a}}$ & $4.60^{\mathrm{a}}$ & $2.26^{\mathrm{a}}$ & $2433.3^{\mathrm{bcdc}}$ \\
\hline \multirow[t]{4}{*}{ Organically } & $\mathrm{T}_{5}$ & $0.164^{\mathrm{cfg}}$ & $92.47^{f}$ & $787.26^{\mathrm{cd}}$ & $8.29^{\mathrm{bc}}$ & $1.15^{\mathrm{c}}$ & $20.40^{c}$ & $3.24^{\mathrm{dc}}$ & $1.79^{\mathrm{cd}}$ & $1800.0^{\mathrm{cf}}$ \\
\hline & $\mathrm{T}_{6}$ & $0.167^{\mathrm{dcf}}$ & $191.94^{\mathrm{d}}$ & $810.00^{c}$ & $8.62^{\mathrm{bc}}$ & $1.26^{\mathrm{b}}$ & $20.32^{c}$ & $3.51^{\mathrm{c}}$ & $1.85^{\mathrm{bc}}$ & $2366.7^{\mathrm{cdc}}$ \\
\hline & $\mathrm{T}_{7}$ & $0.196^{\mathrm{b}}$ & $229.05^{b}$ & $920.61^{a}$ & $10.39^{\mathrm{a}}$ & $1.36^{\mathrm{a}}$ & $23.16^{\mathrm{b}}$ & $4.51^{\mathrm{a}}$ & $2.14^{\mathrm{a}}$ & $2433.3^{\mathrm{bcdc}}$ \\
\hline & $\mathrm{T}_{8}$ & $0.166^{\mathrm{cf}}$ & $174.42^{\mathrm{c}}$ & $788.47^{\mathrm{cd}}$ & $8.44^{\mathrm{bc}}$ & $1.16^{\mathrm{c}}$ & $20.99^{c}$ & $3.40^{\mathrm{cd}}$ & $1.83^{\mathrm{bcd}}$ & $2233.3^{\mathrm{dc}}$ \\
\hline \multirow{6}{*}{ Integrated } & $\mathrm{T}_{9}$ & $0.168^{\text {def }}$ & $211.67^{\mathrm{bc}}$ & $810.00^{c}$ & $8.69^{\mathrm{bc}}$ & $1.17^{c}$ & $21.26^{c}$ & $3.26^{\mathrm{de}}$ & $1.87^{\mathrm{bc}}$ & $2766.7^{\mathrm{bcd}}$ \\
\hline & $\mathrm{T}_{10}$ & $0.178^{\mathrm{cd}}$ & $216.09^{b c}$ & $858.19^{\mathrm{b}}$ & $9.01^{\mathrm{b}}$ & $1.28^{\mathrm{b}}$ & $23.40^{\mathrm{b}}$ & $3.62^{c}$ & $1.93^{\mathrm{b}}$ & $3666.7^{a}$ \\
\hline & $\mathrm{T}_{11}$ & $0.175^{\mathrm{cdc}}$ & $212.50^{\mathrm{bc}}$ & $851.95^{\mathrm{b}}$ & $8.76^{\mathrm{bc}}$ & $1.26^{\mathrm{b}}$ & $22.52^{b}$ & $3.52^{c}$ & $1.87^{\mathrm{bc}}$ & $3190.01^{b}$ \\
\hline & $\mathrm{T}_{12}$ & $0.149^{\mathrm{hi}}$ & $89.16^{\mathrm{f}}$ & $770.11^{\mathrm{d}}$ & $7.94^{\mathrm{bc}}$ & $1.12^{\mathrm{c}}$ & $17.75^{\mathrm{d}}$ & $3.04^{\mathrm{cf}}$ & $1.71^{\mathrm{dc}}$ & $2733.3^{\text {bcd }}$ \\
\hline & $\mathrm{T}_{13}$ & $0.160^{\mathrm{fg}}$ & $208.77^{\mathrm{cd}}$ & $787.26^{\mathrm{cd}}$ & $8.08^{b c}$ & $1.13^{c}$ & $18.54^{\mathrm{d}}$ & $3.25^{\mathrm{dc}}$ & $1.75^{\mathrm{cdc}}$ & $3153.3^{\text {abc }}$ \\
\hline & $\mathrm{T}_{14}$ & $0.154^{\mathrm{gh}}$ & $90.54^{\mathrm{f}}$ & $786.60^{\mathrm{cd}}$ & $8.02^{\mathrm{bc}}$ & $1.14^{c}$ & $20.85^{c}$ & $3.09^{\mathrm{cf}}$ & $1.75^{\mathrm{cdc}}$ & $3116.7^{\mathrm{abc}}$ \\
\hline Control & $\mathrm{T}_{15}$ & $0.033^{k}$ & $74.16^{\mathrm{f}}$ & $693.21^{\mathrm{f}}$ & $6.35^{\mathrm{d}}$ & $0.94^{\mathrm{c}}$ & $16.63^{\mathrm{c}}$ & $2.65^{\mathrm{g}}$ & $1.54^{\mathrm{f}}$ & $1366.7^{\mathrm{f}}$ \\
\hline
\end{tabular}

$\mathrm{T}_{1}$ : Supplying $100 \%$ nitrogen required from urea; $\mathrm{T}_{2}$ : Supplying $100 \%$ nitrogen required from urea +9 ton.ha ${ }^{-1}$ zeolite mixed into the soil; $T_{3}$ : Supplying $100 \%$ nitrogen required from cattle manure compost; $\mathrm{T}_{4}$ : Supplying $100 \%$ nitrogen required from cattle manure compost amended with $10 \%$ (w/w) zeolite; $\mathrm{T}_{5}:$ Supplying $70 \%$ nitrogen required from cattle manure compost; $T_{6}$ : Supplying $70 \%$ nitrogen required from cattle manure compost amended with $10 \%$ (w/w) zeolite; $T_{7}:$ Supplying $100 \%$ nitrogen required from cattle manure compost +9 ton.ha-1 zeolite mixed into the soil; $\mathrm{T}_{8}$ : Supplying $70 \%$ nitrogen required from cattle manure compost +9 ton.ha ${ }^{-1}$ zeolite mixed into the soil; $\mathrm{T}_{9}$ : Supplying 50\% nitrogen required from cattle manure compost and $50 \%$ from urea; $\mathrm{T}_{10}$ : Supplying $50 \%$ nitrogen required from cattle manure compost and $50 \%$ from urea amended with $10 \%(\mathrm{w} / \mathrm{w})$ zeolite; $\mathrm{T}_{11}$ : Supplying $50 \%$ nitrogen required from cattle manure compost and $50 \%$ from urea +9 ton.ha ${ }^{-1}$ zeolite mixed into the soil; $\mathrm{T}_{12}$ : Supplying $70 \%$ nitrogen required from urea and $30 \%$ from cattle manure compost; $\mathrm{T}_{13}:$ Supplying $70 \%$ nitrogen required from urea and $30 \%$ from cattle manure compost amended with $10 \%(\mathrm{w} / \mathrm{w})$ zeolite; $\mathrm{T}_{14}:$ Supplying $70 \%$ nitrogen required from urea and $30 \%$ from cattle manure compost +9 ton.ha ${ }^{-1}$ zeolite mixed into the soil; $\mathrm{T}_{15}$ : control (without any treatments)

pared with chemical or integrated plots. The lowest potassium content was achieved from control treatment without any fertilizing. The results obtained indicate that the increase of the available potassium comes only from the potassium released from cattle manure, and adding zeolite had not a significant effect on potassium content in full organic plots (Tab. 5). In integrated plots an increase of potassium content was observed due to the zeolite application when T9 and T10 treatments were compared. Some authors have also shown an increase in available potassium after organic amendment (Bulluck et al., 2002; Edmeades, 2003). In a three year study, Andrews et al. (2002) found higher potassium values in organic systems. They attributed the result of the high potassium content of the compost and the increase of exchange sites due to organic matter added, which do not fix potassium strongly. Also, Clark et al. (1998) also observed an increase in available potassium in organic and low-input systems.

Left over of micronutrient contents $(\mathrm{Fe}, \mathrm{Cu}, \mathrm{Mn}$ and $\mathrm{Zn}$ ) were different in each group of nutrition managements (Tab. 5). Micronutrient content was the highest with full organically application and $10 \%$ zeolite. The lowest $\mathrm{Fe}, \mathrm{Cu}$ and $\mathrm{Zn}$ content was observed in control treatment, while the lowest Mn content was in full chemical $\left(\mathrm{T}_{1}\right.$ and $\left.\mathrm{T}_{2}\right)$ and control treatments $\left(\mathrm{T}_{15}\right)$. In integrated plots $\mathrm{T}_{10}$ treatment had more $\mathrm{Cu}, \mathrm{Mn}$ and $\mathrm{Zn}$ content than $\mathrm{T}_{\text {o }}$ treatment but this comparison was not significant for $\mathrm{Fe}$ ( Tab. 5). In sum, among integrated plots $\mathrm{T}_{10}$ was best treatment with respect to micronutrient leave. Organic compounds gives a higher input, especially of $\mathrm{Zn}$ and $\mathrm{Cu}$, than do chemical fertilizers, as both these elements contained in feedstuffs are excreted by animals to a large extent. Composted cattle manure, has shown positive effects on microbial activity and supports humus formation in soil (Mäder et al., 2002). These components can form complexes with micronutrients that are not plant available; $\mathrm{Cu}$ and $\mathrm{Zn}$ are known to form stable complexes with organic matter in soil. On the other hand, a high microbial activity can enhance the plant-serving pools. Nyiraneza et al. (2009) have been reported that, long-term application of manure significantly increased soil $\mathrm{K}, \mathrm{Mg}$, and $\mathrm{Zn}$ contents. Manure also increased $\mathrm{P}, \mathrm{Ca}, \mathrm{Fe}$, and $\mathrm{Mn}$ contents by 65, 32, 1.7, and $17 \%$, respectively while nitrogen application significantly decreased soil P, K, Mg, Fe, and Mn contents (Nyiraneza et al., 2009). Moreover, it was found that zeolite had a positive effect on micronutrient residues (Tab. 5). Comparison between $\mathrm{T}_{3}$ and $\mathrm{T}_{4}$ treatment and $\mathrm{T}_{3}$ and $\mathrm{T}_{7}$ treatment confirms this result.

Soil organic carbon content was found to be considerably greater in full organic plots $\left(\mathrm{T}_{3}, \mathrm{~T}_{4}\right.$ and $\left.\mathrm{T}_{7}\right)$ compared to those receiving chemical fertilizer or integrated treatments (Tab. 5). The lowest organic carbon content was observed in full chemical $\left(\mathrm{T}_{1}\right.$ and $\left.\mathrm{T}_{2}\right)$ and control treatment. In integrated plots $\mathrm{T}_{10}$ treatment had the highest organic carbon compared with other integrated plots (Tab. 5). The difference of organic fertilization between organic and 
chemical or integrated plots was evident, due to the addition of composted cattle manure. The addition of composted cattle manure increases the organic carbon content in the soil. Andrews et al. (2002) reported that the application of composts increased organic carbon compared with conventional fertilizing. Scow et al. (1994) reported that organic matter increased after alternate the application of compost.

There were not considerable differences among treatments with respect to seed yield nonetheless the highest seed yield was achieved from $T_{10}, T_{13}$ and $T_{14}$ treatments. Seed yield for all the treatments were greater than the control one (Tab. 5). Yields of crops grown either with organic or mineral fertilization can be equivalent (Warman, 2005). Drinkwater et al. (1995) suggested that other components such as cultivar and management skill were more significant in determining yields than the specific type of input or cultural practice employed.

\section{References}

Allen, E., L. Hossner, D. Ming and D. Henninger (1993) Solubility and cation exchange in phosphate rock and saturated clinoptilolite mixtures. Soil Sci. Soc. Am. J. 57: 1368-1374.

Andrews, S. S., J. P. Mitchell, R. Mancinelli, D. L. Karlen, T. K. Hartz, W. R. Horwarth, G. S. Pettygrove, K. M. Scow and D. S. Munk (2002). On-farm assessment of soil quality in California’s Central Valley. Agron. J. 94:12-23.

Aulakh, M. S. and N. S. Pasricha (1997). Fertilizer nitrogen management and environment pollution-Indian scenario, p. 296-313. In: Kanwar, J.S. and J.C. Katyal (Eds.). Plant nutrient needs, supply, efficiency and policy issues: 20002025. National Academy of Agricultural Science, New Delhi.

Bulluck, L. R., M. Brosius, G. K. Evanylo and J. B. Ristaino (2002). Organic and synthetic amendments influence soil microbial, physical and chemical properties on organic and conventional farms. Appl. Soil Ecol. 19:147-160.

Butorac, A., T. Filipan, F. Basic, J. Butorac, M. Mesic and I. Kisic (2002). Crop response to the application of special natural amendments based on zeolite tuff. Rostlinná Výroba 48: 118-124. (In Czech)

Clark, MS., WR. Horwath and C. Shennan (1998). Changes in soil chemical properties resulting form organic and lowinput farming practices. Agron J. 90:662-671.

Daković, A., M. Tomašević-Čanović, E. G. Rottinghaus, S. Matijašević and Ž. Sekulić (2007). Fumonisin B1 adsorption to octadecyldimetylbenzyl ammoniummodified clinoptilolite-rich zeolitic tuff. Microporous and Mesoporous Materials 105:285-290.

Darwish, O.H., N. Persaud and D.C. Martens (1995). Effect of long-term application of animal manure on physical properties of three soils. Plant Soil 176:289-295.

Drinkwater, L. E., D. K. Leturneau, F. B. Van Workneh and A. H. Shennan (1995). Fundamental difference between conventional and organic tomato agroecosystems. Calif. Ecol. Appl. 5:1098-1112.
Edmeades, D. C. (2003). The long-term effects of manures and fertilisers on soil productivity and quality: A review. Nutr. Cycling Agroecosyst. 66:165-180.

Eghball, B. (2002). Soil properties as influenced by phosphorusandnitrogen-based manure and compost applications. Agron. J. 94:128-135.

Eghball, B. and J. F. Power (1999). Phosphorus and nitrogenbase dmanure and compost application: Corn production and soil phosphorus. Soil Sci. Soc. Am. J. 63:895-901.

Ganzhara, N. F. (1998). Humus, soil properties and yield. Eurasian Soil Science 31:738-745.

Nyiraneza, J. M., H. Chantigny, A. N. D. Ayegamiye and M. R. Laverdière (2009). Dairy Cattle Manure Improves Soil Productivity in Low Residue Rotation Systems. Agron J 101:207-214.

Laboski, C. A. M. and J. A. Lamb (2003). Changes in soil test phosphorus concentration after application of manure or fertilizer. Soil Sci. Soc. Am. J. 67:544-554.

Mäder, P. A. Fliessbach, D. Dubois, L. Gunst, P. Fried and U. Niggli (2002). Soil Fertility and Biodiversity in Organic Farming. Science 296:1694-1697.

Mugwira, L. M. (1979). Residual effects of dairy manure on millet andrye forage and soil properties. J. Environ. Qual. 8:251-255.

Podlešáková, E. J. Kremer and K. Bičovský (1967). Die Umtauschreaktion des Kaliums und Natriums am Bentonit von Braňany. Zeitschrift für Pflanzenernährung Bodenkunde116:1-10.

Polat, E. M. Karaca., H. Demir and A. Naci-Onus (2004). Use of natural zeolite (clinoptilolite) in agriculture. Journal of Fruit Ornamental and Plant Research 12:183-189.

Ruiz, J. C. (2002). Influencia del cambio de un sistema de nutricio'n mineral o orga' nica en las propiedades de suelos hortı' colas de regadı' o. Ph.D. Universidad de Co'rdoba.

Sanyal, S.K. and S.K. DeDatta (1991). Chemistry of phosphorus transformations in soil. Adv. Soil Sci. 16:1-120.

Scheller, E. and J. Raupp (2005). Amino acid and soil organic matter content of topsoil in a long term trial with farmyard manure andmineral fertilizer. Biol. Agric. Hortic. 22:379397.

Scow, K. M., O. Somasco, N. Gunapala, S. Lau, R. Venette, H. Ferris, R. Miller and C. Shenan (1994). Transition from conventional to lowinput agriculture changes soil fertility and biology. Calif. Agric. 48(5):20-26.

Tisdale, S. L., W. L. Nelson and J. D. Beaton (1985). Soil fertility and fertilizers. 4th ed. Macmillan Publ. Co., New York.

Warman, P. R. (2005). Soil fertility, yield an nutrient contents of vegetable crops after 12 years of compost or fertilizer amendments. Biol. Agric. Hortic. 23:85-96.

Wright, R. J., W. D. Kemper, P. D. Millner, J. F. Power and R. F. Korcak (1998). Agricultural uses of municipal, animal, and industrial byproducts. Conservation Research Report 44. U.S. 